\title{
EVALUASI PROGRAM DIKLAT ADMINISTRASI KEPEGAWAIAN PADA BALAI DIKLAT KEAGAMAAN KEMENTERIAN AGAMA JAKARTA (IMPLEMENTASI MODEL EVALUASI KIRKPATRICK)
}

\author{
Fahmy Zakiyuddin \\ Universitas Negeri Jakarta \\ Djaali \\ Universitas Negeri Jakarta
}

\begin{abstract}
This research aims to evaluate the Administration Training and Education Program at Religious Training and Education Center in Jakarta. This study adopts a case study method with qualitative approach by using Kirkpatrick evaluation model that consists of reaction, learning, behavior, and result. The source of data consists of Program Coordinators, Heads and Employees of the said Work Unit, and the participants of the training who will be analyzed by using the interview, observation, and documentation instrument. The conclusion of this research are: I) the reaction level has met the succes criteria, 2) learning level has met the succes criteria, 3) behavior level has not fully met the succes criteria, and 4) result level has met the succes criteria. The results showed that this DAK Program has, in general, met the succes criteria, but there are some aspects that need to be improved in order to achiveve the goals of the program.
\end{abstract}

Keywords
DAK Program, Kirkpatrick evaluation model

\begin{abstract}
ABSTRAK
Penelitian ini bertujuan untuk mengevaluasi Program Diklat Administrasi Kepegawaian Pada Balai Diklat Keagamaan Kementerian Agama Jakarta. Penelitian ini menggunakan metode studi kasus dengan pendekatan kualitatif menggunakan model evaluasi Kirkpatrick yang terdiri dari level reaction, learning, behavior, dan result. Sumber data berasal dari Koordinator Program, Pimpinan dan pegawai Unit Kerja, serta peserta pelatihan dengan menggunakan instrumen wawancara, observasi, dan dokumentasi. Hasil penelitian adalah: I) level reaction sudah memenuhi kriteria keberhasilan, 2) level learning sudah memenuhi kriteria keberhasilan, 3) level behavior belum sepenuhnya memenuhi kriteria keberhasilan, dan 4) level result sudah memenuhi kriteria keberhasilan. Dapat disimpulkan bahwa secara umum pelaksanaan Program DAK tersebut sudah cukup berhasil, namun terdapat beberapa aspek/komponen yang perlu diperbaiki dan ditingkatkan demi tercapainya tujuan program.
\end{abstract}

Kata Kunci

Program Diklat Administrasi Kepegawaian, model evaluasi Kirkpatrick

\section{Pendahuluan}

Menurut Mudyahardjo, pengertian pendidikan dalam arti luas adalah keseluruhan pengalaman belajar setiap orang sepanjang hidupnya (Redja, 2008).

Pendidikan sebagai pengalaman belajar berlangsung tidak saja dalam dunia pendidikan formal (persekolahan) saja tetapi dalam lingkungan sosial juga lingkungan alam dan berlangsung sepanjang hayat. Selanjutnya menurut Mudyohardjo, pendidikan dalam arti sempit dikenal dengan sekolah ataupun persekolahan.
Sekolah adalah lembaga pendidikan formal sebagai salah satu hasil rekayasa peradaban manusia. Jadi, pendidikan dalam arti sempit adalah pengaruh yang diupayakan dan direkayasa sekolah terhadap anak dan remaja yang diserahkan kepada pihak sekolah agar mereka mempunyai kemampuan yang sempurna dan kesadaran penuh terhadap hubungan-hubungan dan tugas-tugas sosial mereka (Redja, 2008).

Filsuf pendidikan John Dewey dalam Jhonson (2006), mengingatkan kita bahwa teori pada akhirnya dan seyogyanya menjadi sesuatu yang 
praktis. Berbagai teori muncul silih berganti dengan daya atraktif masing-masing. Sering teori atau pendekatan itu merupakan sinergi dari berbagai pendekatan dalam berbagai cabang atau disiplin ilmu. Hakekat pendidikan adalah memanusiakan manusia, mengembangkan potensi dasar peserta didik agar berani dan mampu menghadapi problema yang dihadapi tanpa rasa tertekan, mampu, dan senang meningkatkan fitrahnya sebagai khalifah di muka bumi (Harizal, 20II).

Pendidikan dan pelatihan dalam pengembangan sumber daya manusia mempunyai dua dimensi utama, yaitu: dimensi personal dan organisasional. Keduanya harus dikembangkan secara tepat, simultan, dan berkelanjutan (Basri, 2015). Pendidikan dan pelatihan merupakan salah satu cara upaya yang dilakukan untuk meningkatkan sumber daya manusia. Menurut Phillips yang mendefinisikan sumber daya manusia adalah "Human Resources Development is used instead of training and development (Philip, 199)."

Pendidikan dan pelatihan merupakan upaya untuk mengembangkan sumber daya manusia, terutama untuk pengembangan aspek kemampuan intelektual dan kepribadian manusia. Penggunaan istilah pendidikan dan pelatihan dalam suatu institusi sering dijadikan satu menjadi Diklat (pendidikan dan pelatihan). Akan tetapi, keduanya mengandung perbedaan dalam beberapa hal (Basri, 20I5).

Latar belakang penelitian ini bersumber dari banyaknya pemberitaan dan hasil penilaian berbagai pihak terkait rendahnya kualitas Sumber Daya Manusia (SDM), khususnya aparatur di lingkungan pemerintahan di Indonesia, dalam hal ini Kementerian Agama, dengan salah satu yang menjadi penyebabnya adalah kurang optimalnya penempatan pegawai. Penelitian ini bertujuan untuk mengevaluasi Program DAK tersebut guna memperoleh gambaran terkait pelaksanaan program, mulai dari perencanaan, pelaksanaannya yang dikemas dalam bentuk pelatihan melalui kegiatan diskusi pendahuluan dan penyampaian materi DAK, hingga sampai tahap pemantauan hasilnya.

Pada penelitian ini peneliti fokus pada pelaksanaan program dengan melakukan analisis secara komprehensif terhadap pelaksanaan program DAK tersebut, apakah dilaksanakan secara baik sehingga memberikan pengaruh positif khususnya pada pegawai peserta pelatihan serta dampaknya terhadap kinerja satker dan institusi.

Berubahnya struktur dan mekanisme kerja dalam lingkungan organisasi pemerintah menuntut aparaturnya untuk memiliki wawasan, pengetahuan, skill, pola pikir, dan cara baru yang sesuai dengan kebutuhan organisasi pemerintah. Untuk beradaptasi pada situasi yang baru menuntut aparatur pemerintah harus kreatif, inovatif, proaktif, dan berwawasan entrepreneurial.

Pembentukan sosok pegawai negeri sipil yang memiliki kompetensi pengetahuan, keterampilan, dan sikap perilaku yang diperlukan dalam melaksanakan tugas jabatannya, perlu dididik dan dilatih agar dapat bekerja dengan efektif dan efesien sesuai dengan tuntutan pekerjaan, tugas dan fungsi pegawai yang bersangkutan. Tuntutan pekerjaan, tugas dan fungsi dimaksud adalah terwujudnya spesialisasi yang dipersyaratkan jabatan yang ditentukan guna memenuhi kebutuhan organisasi termasuk pengadaan kader pimpinan dan staf.

Pendidikan dan pelatihan Pegawai Negeri Sipil (Diklat PNS) dalam jabatan terdiri dari tiga jenis, yaitu: pendidikan dan pelatihan struktural (kepemimpinan), pendidikan dan pelatihan fungsional, dan pendidikan dan pelatihan teknis.

Sebuah pelatihan (training) dapat dikatakan berhasil bila para peserta dapat menerima dan mengalami peningkatan pengetahuan (knowledge), keterampilan (skill), maupun perilaku (attitude) yang tepat dan diberikan oleh instruktur yang tepat pula serta menggunakan metode dan media yang didesain khusus guna pencapaian peningkatan kinerja/kompetensi pegawai. Hal ini dapat diketahui bila diadakan evaluasi pelatihan (training) secara berkelanjutan dan terprogram.

Tujuan diadakannya Diklat di tempat kerja bagi Pegawai Negeri Sipil (PNS), yaitu: diharapkan Pegawai Negeri Sipil (PNS) mampu mengembangkan aspek kemampuan intelektual dan kepribadian manusia. Agar Pegawai Negeri Sipil (PNS) mempunyai keahlian khusus yang berhubungan dengan pekerjaan yang telah di amanahkannya. 
Fahmy Zakiyuddin

Djaali

Aparatur pemerintah/PNS sebagai unsur utama SDM, aparatur negara mempunyai peranan yang strategis dan menentukan keberhasilan penyelenggaraan pemerintah dan pembangunan. Sosok aparatur yang mampu memainkan peran tersebut adalah aparatur yang mempunyai kompetensi yang diindikasikan dari sikap dan perilakunya yang penuh dengan kesetiaan dan ketaatan, bermoral dan bermental baik, profesional, sadar akan tanggungjawabnya, serta mampu menjadi perekat persatuan dan kesatuan bangsa.

Dalam membangun sosok Aparatur sebagaimana yang disebutkan di atas, maka pemerintah perlu membina aparatur secara terus menerus dengan jelas, terarah dan transparan sebagai salah satu tujuan untuk mengembangkan pola karier dan prestasi kerja bagi setiap aparatur melalui pelaksanaan diklat-diklat. Dengan pola karier yang jelas, terarah, dan transparan akan dapat merangsang pegawai untuk mengembangkan karier dan profesionalisme.

Tak dapat dipungkiri, bahwa pendidikan dan pelatihan merupakan salah satu pendekatan utama dalam mengembangkan sumber daya manusia. Hal ini dilakukan sebagai pendekatan, karena pendidikan dan pelatihan mempunyai peran strategis terhadap keberhasilan mencapai tujuan organisasi, baik pemerintah maupun swasta.

Maksud diupayakannya Diklat bagi setiap pegawai diharapkan akan meningkatkan pengetahuan, keahlian, keterampilan, dan sikap untuk dapat melaksanakan tugasnya secara profesional dengan dilandasi kepribadian dan etika sesuai dengan kebutuhan instansi. Di samping itu juga Diklat dimaksudkan untuk menciptakan kesamaan visi dan dinamika pola pikir dalam melaksanakan tugas pemerintahan umum dan pembangunan demi terwujudnya pemerintahan yang baik, memantapkan sikap dan semangat pengabdian yang berorientasi pada pelayanan, pengayoman dan pemberdayaan masyarakat. Serta menciptakan aparatur yang mampu berperan sebagai pembaharu dan perekat persatuan dan kesatuan bangsa, sasaran Diklat adalah untuk mewujudkan kinerja aparatur yang memiliki kompetensi sesuai dengan persyaratan jabatan masing-masing, serta membangun sikap
Evaluasi Program Diklat Administrasi Kepegawaian Pada Balai Diklat Keagamaan Kementerian Agama Jakarta (Implementasi Model Evaluasi Kirkpatrick) positif dan mandiri bagi setiap aparatur dalam melaksanakan tugasnya.

Kegunaan hasil penelitian evaluasi program Diklat Administrasi Kepegawaian pada Balai Diklat Keagamaan Kota Jakarta adalah tersedianya informasi yang lengkap tentang tingkat kepuasan (reaction), tingkat pengetahuan (learning), perubahan sikap (behavior), dan hasil atau dampak (result) peserta sebelum dan sesudah mengikuti Diklat Administrasi Kepegawaian pada Balai Diklat Keagamaan Jakarta selaku penyelenggara. Diklat Administrasi Kepegawaian ini, memuat materi bagaimana seorang Pegawai Negeri Sipil dapat membuat Sasaran Kinerja Pegawai (SKP), Analisis Beban Kerja (ABK), dan Analisis Jabatan (ANJAB). Diklat ini diselenggarakan oleh Balai Diklat Keagamaan Jakarta, yang mengambil tempat di Kantor Wilayah Kementerian Agama Provinsi DKI Jakarta. Jumlah peserta yang mengikuti Diklat ini sebanyak 30 peserta, yaitu: 5 peserta perwakilan dari Kantor Wilayah Kementerian Agama Provinsi DKI Jakarta, 5 peserta perwakilan dari Kantor Kementerian Agama Kota Administrasi Jakarta Utara, 5 peserta perwakilan dari Kantor Kementerian Agama Kota Administrasi Jakarta Pusat, 5 peserta perwakilan dari Kantor Kementerian Agama Kota Administrasi Jakarta Barat, 5 peserta perwakilan dari Kantor Kementerian Agama Kota Administrasi Jakarta Timur, dan 5 peserta perwakilan dari Kantor Kementerian Agama Kota Administrasi Jakarta Selatan. Untuk memperoleh data tentang reaction dan learning menggunakan 30 peserta sebagai sampel, namun untuk memperoleh data tentang behavior dan result menggunakan 3 sampel satker (satuan kerja), yaitu: Kantor Kementerian Agama Kota Administrasi Jakarta Selatan, Kantor Kementerian Agama Kota Administrasi Jakarta Pusat, dan Kantor Wilayah Kementerian Agama Provinsi DKI Jakarta.

Diperolehnya informasi akurat dan detail tentang tingkat keberhasilan serta faktor-faktor yang menjadi penyebab sehingga penyelenggaraan Diklat Administrasi Kepegawaian tidak sesuai dengan tujuan yang telah ditetapkan. Informasi tersebut dapat dijadikan sebagai rujukan (referensi) dalam meningkatkan kualitas 
penyelenggaraan Diklat Administrasi Kepegawaian (DAK).

Sebagai informasi bagi para pengambil kebijakan (stakeholder), baik tingkat pusat maupun daerah dalam mendukung keberhasilan penyelenggaraan Diklat Administrasi Kepegawaian yang berkualitas dan berorientasi pada tujuan serta kebutuhan perserta/instansi.

\section{Metode Penelitian}

Seperti telah diuraikan sebelumnya bahwa model evaluasi yang digunakan adalah model evaluasi Kirkpatrick, yang menurut Peneliti memiliki beberapa kelebihan sebagaimana dijelaskan sebelumnya, terutama pada metodenya yang sederhana, mudah diterapkan, dan memberikan ruang yang cukup besar bagi Peneliti dalam melakukan metode analisis pada tiap variabel ataupun tahapan evaluasinya. Jadi dalam pelaksanaan evaluasi program DAK (Diklat Administrasi Kepegawaian) ini, mengacu pada indikator-indikator yang terdapat pada tiap tahapan/level model evaluasi Kirkpatrick, yakni: reaction, learning, behavior, dan result, dengan beberapa modifikasi dan tambahan metode analisis yang Peneliti gunakan demi kesempurnaan penelitian.

Penelitian evaluasi program ini menggunakan metode studi kasus dengan pendekatan kualitatif menggunakan model evaluasi Kirkpatrick yang terdiri dari 4 tahap/level, yakni: reaction, learning, behavior, dan result. Sumber data berasal dari Koordinator Program, Pimpinan dan pegawai Unit Kerja, serta peserta pelatihan dengan menggunakan instrumen angket, tes tertulis (PreTest dan Post-Test), wawancara, observasi, dan dokumentasi.

Selain data kualitatif, Peneliti juga mengumpulkan data yang sifatnya kuantitatif berupa angka-angka dari hasil pengukuran berkaitan dengan angket/kuesioner yang Peneliti gunakan. Data kuantitatif lain adalah data statistik dari satker, misalnya data pegawai, pejabat, dan skor-skor atau indeks-indeks hasil penilaian.

Mengenai sumber data dapat berupa sumber data primer dan sumber data sekunder. Di sini peneliti juga merupakan instrumen kunci. Selain itu sumber data yang lain adalah pimpinan satker, atasan langsung atau rekan kerja pegawai, pegawai peserta pelatihan itu sendiri, koordinator/admin program, dan staf lainnya. Pemilihan sumber data beberapa diantaranya dari keseluruhan populasi, sebagian lainnya diambil melalui sampling secara purposive sampling, misalnya pada penelitian ini, data dari non-peserta pelatihan sebagai kelompok pembanding diambil hanya beberapa pegawai pada satker, pimpinan satker atau koordinator maupun admin terhadap leading sector program DAK juga hanya kepada beberapa orang. Selain itu, akan digunakan juga cara pengambilan sampling dengan snowballsampling untuk pengambilan data dari pimpinan satker, sebab yang lebih mengerti akan informasi yang dibutuhkan adalah pimpinan suatu bidang atau seksi yang berkaitan langsung dengan kegiatan/informasi tersebut. Sumber data sekunder lainnya, yaitu: dari data stastistik, data pada situs internet yang kredibel, arsip dokumen dan records, baik resmi ataupun dokumen pribadi.

Di samping itu, pada penelitian ini juga data kualitatif dikumpulkan dari dokumen atau catatan. Untuk keperluan itu, dokumen juga perlu dianalisis isinya. Oleh karena itu, khusus untuk analisis dokumen para ahli juga mengembangkan model-model analisis isi atau juga sering disebut analisis isi atau analisis konten (content analysis). Dengan demikian, pada penelitian evaluasi ini Peneliti menggunakan gabungan dari pendapat para ahli analisis data penelitian kualitatif, juga analisis konten/isi kualitatif. Data-data dari hasil wawancara, dokumentasi, dan observasi dibuat transkrip, diproses, disortir lalu dikategorisasi. Proses tersebut bersifat iteratif sebagai cek-silang yang berfungsi sebagai konfirmasi data. Proses analisis ini berlanjut sampai ditetapkan suatu tema atau hubungan. Sedangkan untuk analisis data kuantitatif dalam penelitian evaluasi ini menggunakan statistik deskriptif. Data-data yang sifatnya kuantitatif berupa angka-angka, baik skor hasil penilaian maupun angket, diterjemahkan dalam sebuah simpulan sesuai kebutuhan analisis yang dibutuhkan dalam penelitian/evaluasi.

\section{Hasil Penelitian dan Pembahasan}

Yang menjadi indikatornya pada level reaction, yaitu: Bagaimana tingkat kepuasan peserta terhadap Panitia, tingkat kepuasan peserta 
terhadap narasumber atau widyaiswara, tingkat kepuasan peserta terhadap modul/slide presentasi, dan tingkat kepuasan peserta terhadap game/simulasi. Pada indikator pertama, yaitu: tingkat kepuasan peserta terhadap panitia, indikator yang pertama ini terdiri dari 12 pertanyaan, yaitu: I) penetapan peserta diklat, 2) penyampaian undangan peserta diklat, 3) kesiapan panitia penyelenggara, 4) ketepatan waktu diklat, 5) ketertiban acara diklat, 6) pelayanan akomodasi diklat, 7) pelayanan konsumsi diklat, 8) kebersamaan/kekompakan panitia diklat, 9) perilaku/pelayanan panitia diklat, 10) pakaian panitia diklat, II) kesiapan sarana dan prasarana diklat, dan I2) penguasaan IT pantia diklat. Hasil analisis Peneliti pada level evaluasi reaction indikator yang pertama menunjukkan bahwa pelaksanaan program Diklat Administrasi Kepegawaian (DAK) pada Kanwil Kementerian Agama Provinsi DKI Jakarta, Kantor Kementerian Agama Kota Administrasi Jakarta Pusat, Kantor Kementerian Agama Kota Administrasi Jakarta Selatan, Kantor Kementerian Agama Kota Administrasi Jakarta Timur, Kantor Kementerian Agama Kota Administrasi Jakarta Utara, dan Kantor Kementerian Agama Kota Administrasi Jakarta Barat Tahun 2016 dikategorikan Berhasil (Memenuhi Kriteria Keberhasilan). Dengan demikian secara keseluruhan dapat pula disimpulkan bahwa pada level evaluasi reaction, pelaksanaan program DAK secara umum pada Balai Diklat Keagamaan Jakarta dikategorikan Berhasil Keberhasilan).

\section{(Memenuhi}

Kriteria

Pada indikator kedua tingkat kepuasan peserta terhadap widyaiswara atau narasumber. Indikator yang kedua ini terdiri dari 13 butir pertanyaan, yaitu: I) penguasaan materi/modul, 2) teknik presentasi/penyampaian materi, 3) ketepatan penggunaan metode, 4) pemanfaatan sarana/ media TI, 5) kesesuaian sistematika modul dengan penyampaian materi, 6) gaya penyampaian materi, 7) teknik memotivasi peserta, 8) kematangan emosional dalam penyajian materi, 9) penggunaan bahasa, 10) jawaban terhadap pertanyaan peserta, II) sikap dan penampilan narasumber dalam menyajikan materi, 12) pencapaian target materi, dan 13) penguasaan kelas/peserta. Hasil analisis Peneliti pada level evaluasi reaction indikator yang kedua menunjukkan bahwa pelaksanaan program Diklat Administrasi Kepegawaian (DAK) pada Kanwil Kementerian Agama Provinsi DKI Jakarta, Kantor Kementerian Agama Kota Administrasi Jakarta Pusat, Kantor Kementerian Agama Kota Administrasi Jakarta Selatan, Kantor Kementerian Agama Kota Administrasi Jakarta Timur, Kantor Kementerian Agama Kota Administrasi Jakarta Utara, dan Kantor Kementerian Agama Kota Administrasi Jakarta Barat Tahun 2016 dikategorikan Berhasil (Memenuhi Kriteria Keberhasilan). Dengan demikian secara keseluruhan dapat pula disimpulkan bahwa pada level evaluasi reaction, pelaksanaan program DAK secara umum pada Balai Diklat Keagamaan Jakarta dikategorikan Berhasil (Memenuhi Kriteria Keberhasilan).

Pada indikator ketiga tingkat kepuasan peserta terhadap modul/slide presentasi. indikator yang ketiga ini terdiri dari 10 butir pertanyaan, yaitu: I) format penulisan modul, 2.a) tampilan slide presentasi, b) kesesuaian video dengan materi, c) teks mewakili subtansi materi, d) proporsional font dan size teks, e) keserasian warna, f) kenyamanan dalam melihat slide, 3) sistematika dalam penulisan buku modul, 4) sistematika dalam tayangan slide presentasi dan CD, 5) bahasa yang digunakan dalam buku modul, 6) bahasa yang digunakan tayangan slide presentasi dan $C D, 7$ ) isi/materi modul, 8) keterkaitan judul dengan isi/materi dalam modul/slide, 9) keterkaitan tujuan pembelajaran dengan uraian materi, dan 10) kesinambungan materi antar bab dalam modul/slide. Hasil analisis Peneliti pada level evaluasi reaction indikator yang ketiga menunjukkan bahwa pelaksanaan program Diklat Administrasi Kepegawaian (DAK) pada Kanwil Kementerian Agama Provinsi DKI Jakarta, Kantor Kementerian Agama Kota Administrasi Jakarta Pusat, Kantor Kementerian Agama Kota Administrasi Jakarta Selatan, Kantor Kementerian Agama Kota Administrasi Jakarta Timur, Kantor Kementerian Agama Kota Administrasi Jakarta Utara, dan Kantor Kementerian Agama Kota Administrasi Jakarta Barat Tahun 2016 dikategorikan Berhasil (Memenuhi Kriteria Keberhasilan). Dengan demikian secara keseluruhan dapat pula disimpulkan bahwa pada level evaluasi reaction, pelaksanaan program DAK 
secara umum pada Balai Diklat Keagamaan Jakarta dikategorikan Berhasil (Memenuhi Kriteria Keberhasilan).

Pada indikator keempat tingkat kepuasan peserta terhadap simulasi/game. indikator yang keempat ini terdiri dari 7 butir pertanyaan, yaitu: I) cara penyampaian, 2) sistematika penyampaian, 3) subtansi simulasi/game, 4) keterkaitan sumulasi/game dengan judul materi modul, 5) keterkaitan simulasi/game dengan tujuan pembelajaran, 6) ketepatan penggunaan sarana, dan 7) manfaat penggunaan simulasi/game. Hasil analisis Peneliti pada level evaluasi reaction indikator yang keempat menunjukkan bahwa pelaksanaan program Diklat Administrasi Kepegawaian (DAK) pada Kanwil Kementerian Agama Provinsi DKI Jakarta, Kantor Kementerian Agama Kota Administrasi Jakarta Pusat, Kantor Kementerian Agama Kota Administrasi Jakarta Selatan, Kantor Kementerian Agama Kota Administrasi Jakarta Timur, Kantor Kementerian Agama Kota Administrasi Jakarta Utara, dan Kantor Kementerian Agama Kota Administrasi Jakarta Barat Tahun 2016 dikategorikan Berhasil (Memenuhi Kriteria Keberhasilan). Dengan demikian secara keseluruhan dapat pula disimpulkan bahwa pada level evaluasi reaction, pelaksanaan program DAK secara umum pada Balai Diklat Keagamaan Jakarta dikategorikan

\section{Berhasil (Memenuhi Kriteria Keberhasilan).}

Yang menjadi indikatornya pada level learning, yaitu: Bagaimana tingkat pengetahuan sebelum dan sesudah mengikuti diklat. Pelaksanaannya pada Kanwil Kementerian Agama Provinsi DKI Jakarta, Kantor Kementerian Agama Kota Administrasi Jakarta Pusat, Kantor Kementerian Agama Kota Administrasi Jakarta Selatan, Kantor Kementerian Agama Kota Administrasi Jakarta Timur, Kantor Kementerian Agama Kota Administrasi Jakarta Utara, dan Kantor Kementerian Agama Kota Administrasi Jakarta Barat Tahun 2016 yang terdiri dari 4 pertanyaan, yaitu: Proses penyusunan Sasaran Kinerja Pegawai, Penyusunan penilaian perilaku kerja, Penyusunan ANJAB (Analisis Jabatan), dan Penyusunan ABK (Analisis Beban Kerja).

Pada tahap ini alat ukur yang digunakan adalah hasil Pre-test dan Post-test peserta pelatihan. Soal tes terdiri dari beberapa pertanyaan di mana antara soal Pre-test dan Post-test hakikatnya sama, namun urutannya saja yang diacak. Hasil tes seluruh peserta kemudian dinilai dan diambil rataratanya. Adapun kriteria keberhasilannya adalah jika rata-rata nilai tes seluruh peserta menunjukkan positif atau ada peningkatan, dengan kata lain minimal terjadi kenaikan skor antara nilai hasil Pre-test peserta pelatihan dibandingkan dengan nilai hasil Post-test (rata-rata Nilai PostTest>Pre-Test).

Jumlah peserta diklat yang akan dilakukan pretest dan post-test sebanyak 23 orang peserta. Di mana semua peserta sebelum mengikuti DAK terlebih dahulu peserta mengisi soal pre-test. Soal pre-test berjumlah 20 soal. Lima soal tentang proses penyusunan sasaran kinerja pegawai, lima soal tentang penyusunan penilaian perilaku kerja, lima soal tentang penyusunan ANJAB (Analisis Jabatan), dan lima soal tentang penyusunan $A B K$ (Analisis Beban Kerja).

Dari hasil pre-test menunjukkan nilai peserta ada yang tinggi dan ada yang mendapatkan nilai rendah. Dari 23 orang perserta I orang peserta yang mendapatkan nilai tinggi, yaitu: 80, 2 orang peserta yang mendapatkan nilai 70,2 orang peserta yang mendapatkan nilai 65,5 orang peserta yang mendapatkan nilai 60,2 orang peserta yang mendapatkan nilai 55, 3 orang peserta yang mendapatkan nilai 50, 3 orang peserta yang mendapatkan nilai 45, 2 orang peserta yang mendapatkan nilai 40, 2 orang peserta yang mendapatkan nilai 30 , dan I orang peserta yang mendapatkan nilai 25 . Jumlah ratarata dari hasil pre-test terhadap 23 orang peserta, yaitu: 53.

Selanjutnya, setelah peserta mengikuti empat hari diklat administrasi kepegawaian, peserta diberikan tes lagi, yaitu: berupa post-test. Soal dari post-test diambil dari soal yang sama dari soal pretest, akan tetapi sudah diacak baik dari segi penomoran soal dan dari pilihan jawaban. Setelah dianalisis ada beberapa peserta diklat yang mengalami penurunan dan peningkatan pengetahuan atau bahkan ada beberapa yang tetap. Dari hasil post-test, 3 orang peserta yang mendapatkan nilai tertinggi, yaitu: nilai 75, 2 orang peserta yang mendapatkan nilai 70, 4 orang peserta mendapatkan nilai 65,4 orang peserta 
mendapatkan nilai 60,6 orang peserta yang mendapatkan nilai 55,3 orang peserta mendapatkan nilai 50, dan I orang peserta yang mendapatkan nilai 40. Jumlah rata-rata nilai peserta yang telah diberikan post-test, yaitu: ratarata nilai $6 \mathrm{I}$.

Kesimpulan dari hasil pre-test dan post-test yang dilakukan kepada 23 orang peserta diklat administrasi kepegawaian, menjelaskan bahwa $56 \%$ atau 13 orang peserta yang mengalami peningkatan atau penambahan pengetahuan setelah menerima materi diklat, sebanyak $34 \%$ atau 8 orang peserta yang mengalami penurunan pengetahuan setelah mendapatkan materi tentang diklat dan $8 \%$ atau 2 orang peserta yang mendapatkan hasil tetap setelah mendapatkan materi diklat.

Dengan demikian secara keseluruhan dapat pula disimpulkan bahwa pada level evaluasi learning, pelaksanaan program DAK secara umum pada Balai Diklat Keagamaan Kementerian Agama dikategorikan Berhasil (Memenuhi Kriteria Keberhasilan).

Namun demikian, beberapa catatan peneliti terkait aspek dan indikator pada level learning yang masih mendapatkan nilai rendah dan perlu menjadi perhatian antara lain: Peningkatan nilai Pre-Test dan Post-Test Peserta masih rendah, tidak terlalu signifikan, khususnya pada pelaksanaan pelatihan DAK di Balai Diklat Keagamaan Jakarta yang hanya naik 7 poin.

Kemudian pada level evaluasi behavior, ada 5 indikator, yaitu: Pegawai mengimplementasikan konsep administrasi kepegawaian pada pekerjaan sehari-hari di kantor, Perubahan aktivitas kerja, Pola interaksi dengan atasan, rekan kerja, dan bawahan, Perilaku Kerja dan kinerja yang dihasilkan paska Diklat, dan Penerapan reward and punishment satker terhadap kinerja pegawai.

Informasi yang berkaitan dengan aspek yang pertama, yaitu: perilaku alumni diklat dalam melakukan konsep administrasi kepegawaian, perubahan aktivitas kerja, pola interaksi pada atasan, rekan kerja, perilaku kerja dan kinerja yang dihasilkan paska diklat, dan penerapan reward and punishment satker terhadap kinerja pegawai dilakukan dalam bentuk observasi dan wawancara.
Informasi tentang kemampuan peserta dalam mengimplementasikan konsep administrasi kepegawaian juga diperoleh melalui observasi dan wawancara. Hasil observasi ditemukan bahwa dari 3 kantor dari alumni diklat yang dikunjungi, terdapat 2 kantor alumni diklat tidak dapat memperlihatkan tentang susunan analisis beban kerja karena memang belum adanya pelatihan khusus yang membahas tentang bagaimana menyusun dan menganalisis beban kerja.

Informasi lain terkait implementasi konsep administrasi kepegawaian juga diperoleh melalui wawancara. Hasil wawancara yang dilakukan terhadap staf di Kantor Kementerian Agama Kota Administrasi Jakarta Pusat " $\mathrm{H}$. Dody Pursaksono, S.Sos, MM" mengatakan bahwa "...selama saya menjabat sebagai staf di bagian kepegawaian, belum ada kegiatan yang membahas tentang bagaimana menyusun dan menganalisis beban kerja seorang pegawai, paling kita belajar sendiri dengan melihat di internet bagaimana di kementerian yang lain dalam menyusun dan menganalisis beban kerja, tetapi kalau mengenai sasaran kinerja (SKP) dan analisis jabatan (ANJAB) sudah ada materi-materi yang disampaikan di acara-acara penataran mengenai kepegawaian."

Jawaban yang berbeda diperoleh dari hasil wawancara oleh staf Kantor Kementerian Agama Kota Administrasi Jakarta Selatan " $H$. Latifudin, MA" mengatakan bahwa "...mungkin ada beberapa staf yang menjabat sebagai kepegawaian sudah pernah mendapatkan materi tentang analisis beban kerja, tetapi kebanyakan pegawai mayoritas belum paham betul tentang analisis beban kerja atau cara menghitung beban kerja seorang pegawai, belum lagi pegawai yang bersangkutan tidak mempunyai waktu yang banyak untuk lebih mendalam mempelajari beban kerja, karena banyak pegawai yang tugasnya sebagai kepegawaian merangkap untuk melaksanakan tugas yang lain, jadi kurang fokus, terus ditambah lagi mutasi antar tugas yang terlalu sering dilakukan oleh suatu satker.

Jawaban lain berdasarkan hasil petikan wawancara oleh staf Ortala dan Kepegawaian Kantor Wilayah Kementerian Agama Provinsi DKI Jakarta, "Drs. Sugito" Untuk menganalisis dan membuat sasaran kinerja pegawai (SKP) dan 
menganalisis jabatan pegawai tertentu lebih mudah dibandingkan dengan menyusun dan menganalisis beban kerja seorang pegawai, dikarenakan kalau menghitung dan menganalisis beban kerja seorang pegawai berkaitan dengan angka-angka dan poinnya. Mungkin dari hal itu, menghitung dan menganalisis beban kerja pegawai lebih rumit.

Berdasarkan hasil wawancara dan observasi untuk mengetahui perubahan perilaku alumni diklat dalam melaksanakan konsep administrasi kepegawaian sudah berjalan dengan baik atau positif, kecuali alumni diklat yang belum menerima materi yang lengkap dari konsep administrasi kepegawaian.

Aspek perilaku alumni diklat yang kedua, yaitu: perubahan aktivitas kerja. Hasil wawancara dan observasi yang dilakukan di Kantor Wilayah Kementerian Agama Provinsi DKI Jakarta di sub bagian Ortala dan Kepegawaian. Jawaban dari Kasubag. Ortala dan Kepegawaian, yaitu: "Drs. Sugito" aktivitas kerja pegawai di kantor yang telah mengikuti diklat administrasi kepegawaian secara keseluruhan terdapat sedikit perbedaan yang mengarah ke positif, yakni sebagian besar sudah mulai termotivasi untuk bekerja lebih disiplin, melaksanakan tugas dan fungsinya juga mengarah lebih baik atau positif, sedangkan iklim kerja dan pola kerja peserta rata-rata masih sama, tidak ada perubahan yang jelas."

Informasi lain hasil observasi wawancara dengan Kepala Tata Usaha Kantor Kementerian Agama Kota Administrasi Jakarta Pusat, "H. Dody Pursaksono, S.Sos, MM" mengatakan bahwa, “...aktivitas kerja di kantor paska diklat secara keseluruhan positif, yakni sebagian besar sudah mulai termotivasi untuk bekerja lebih disiplin lagi, sedangkan iklim dan pola kerja peserta rata-rata masih sama, tidak ada perubahan yang jelas."

Jawaban yang lain dari Kepala Tata Usaha Kantor Kementerian Agama Kota Administrasi Jakarta Selatan, "H. Latifudin, MA" mengatakan bahwa, "...aktivitas kerja pegawai atau peserta di kantor paska diklat secara keseluruhan positif, yakni sebagian besar pegawai yang telah ikut diklat sudah mulai lebih rajin lagi dalam menjalankan tugas dan fungsinya, sedangkan iklim dan pola kerja peserta rata-rata meningkat dan terdapat perubahan yang jelas."
Berdasarkan hasil wawancara dan observasi untuk mengetahui perilaku diklat dalam melaksanakan perubahan aktivitas kerja belum berjalan dengan baik atau negatif, dikarenakan masih ada pegawai atau alumni diklat yang belum berubah berkenaan dengan aktivitas kerjanya.

Aspek perilaku alumni yang ketiga, yaitu: Pola interaksi dengan atasan, rekan kerja dan bawahan. Pola interaksi alumni diklat yang telah mengikuti diklat administrasi kepegawaian, Kasubag. Ortala dan Kepegawaian mengatakan bahwa, “...pola interaksi peserta/pegawai-atasan-rekan kerja cukup baik, bawahan lebih santun dan menghormati pimpinan serta rekan kerja." Jawaban lain dari Kepala Tata Usaha Kantor Kementerian Agama Kota Administrasi Jakarta Pusat, " $\mathrm{H}$. Dody Pursaksono, S.Sos, MM"mengatakan bahwa, “... pola interaksi peserta/pegawai-atasan-rekan kerja cukup baik, bawahan mulai lebih santun dan menghormati pimpinan." Jawaban lain dari Kepala Tata Usaha Kantor Kementerian Agama Kota Administrasi Jakarta Selatan, "H. Latifudin, MA" mengatakan bahwa, "...pola interaksi peserta/pegawai-atasanrekan kerja cukup baik, terbentuknya kerjasama yang saling melengkapi dan saling menghormati antara atasan dengan bawahan dan sesama rekan kerja."

Berdasarkan hasil wawancara dan observasi untuk mengetahui perilaku alumni diklat dalam melaksanakan pola interaksi dengan atasan, rekan kerja dan bawahan sudah berjalan dengan baik atau positif.

Aspek perilaku alumni yang keempat, yaitu: perilaku kerja dan kinerja yang dihasilkan paska diklat. Jawaban dari Kasubag Ortala dan Kepegawaian Kantor Kementerian Agama Provinsi DKI Jakarta, "Drs. Sugito" mengatakan bahwa, "...pegawai/peserta yang telah mengikuti diklat mengalami perubahan perilaku kerja, yaitu: menjadi lebih disiplin lagi dan mengerjakan tugas dan fungsinya sebagai operator kepegawaian, yaitu: mengerjakan sasaran kinerja, analisis jabatan, dan analisis beban kerja." Jawaban lain dari Kepala Tata Usaha Kantor Kementerian Agama Kota Administrasi Jakarta Pusat, "H. Dody Pursaksono, S.Sos, MM" mengatakan bahwa “...perilaku kerja dan kinerja yang dihasilkan paska diklat, yaitu: perilakunya menjadi lebih baik 
dan mampu memberikan masukan kepada rekan kerjanya, kinerja yang dihasilkan menjadi lebih jelas dan terarah, yaitu: pegawai/peserta diklat berusaha dengan sepenuh hati mengerjakan sasaran kinerja, analisis jabatan, dan analisis beban kerja untuk diri sendiri maupun untuk rekan kerjanya."

Jawaban lain dari Kepala Tata Usaha Kantor Kementerian Agama Kota Administrasi Jakarta Selatan, "H. Latifudin, MA" mengatakan bahwa, "...perilaku kerjanya sudah lebih baik, antara rekan kerja saling tegur sapa, sedangkan dengan kinerja yang dihasilkan, yaitu: adanya diskusi kepada atasan dan rekan kerja mengenai pengerjaan sasaran kinerja, analisis jabatan, dan analisis beban kerja."

Berdasarkan hasil wawancara dan observasi untuk mengetahui perilaku dalam melaksanakan perubahan perilaku kerja dan kinerja yang dihasilkan paska diklat berjalan dengan baik atau positif karena ada perubahan yang jelas terhadap aspek perilaku kerja dan kinerja yang dihasilkan paska diklat.

Aspek perilaku alumni yang kelima, yaitu: penerapan reward and punishment satker terhadap kinerja pegawai. Jawaban dari Kasubag Ortala dan Kepegawaian Kantor Kementerian Agama Provinsi DKI Jakarta, "Drs. Sugito" mengatakan bahwa, "... penerapan reward and punishment satker terhadap kinerja pagawai, yaitu: untuk reward pegawai yang kinerja baik akan mendapatkan nilai atau poin yang berasal dari penilaian perilaku kerja dan bagi pegawai yang tidak baik dalam kinerjanya akan dikenakan hukuman sesuai dengan PP 53 tentang disiplin pegawai negeri sipil, contohnya berupa mendapatkan surat panggilan pertama, kedua, dan ketiga, penurunan pangkat jabatan, penundaan kenaikan gaji berkala, dan terakhir diberhentikan sebagai PNS."

Jawaban yang hampir sama dari Kepala Tata Usaha Kantor Kementerian Agama Kota Administrasi Jakarta Pusat, "H.Dody Pursaksono, S.Sos,MM" mengatakan bahwa “... penerapan reward dan punishment sangat berlaku untuk mengendalikan sikap PNS dan mengontrol kinerja apa yang sudah dihasilkan, jika perilaku kerjanya baik akan mendapatkan poin yang tinggi dan berpengaruh terhadap poin penilaian perilaku kinerja, sedengakan untuk hukuman yang akan di terima bagi PNS yang kinerjanya kurang baik akan dikenakan dengan PP 53 tentang disiplin PNS."

Jawaban senada juga diberikan oleh Kepala Tata Usaha Kantor Kementerian Agama Kota Administrasi Jakarta Selatan, "H. Latifudin, MA" mengatakan bahwa, “... untuk masalah penghargaan dan hukuman yang diterapkan oleh satker kepada PNS terkait kinerja sudah lama diterapkan, jika PNS tersebut kurang baik dalam hal kinerja maka akan dikenakan dengan PP 53, yaitu: tentang disiplin PNS, namun jika PNS tersebut menjalankan tugasnya dengan baik sesuai dengan tugas dan fungsinya maka akan berdampak pada penilaian perilaku kinerja yang berupa mendapatkan poin atau nilai yang tinggi."

Berdasarkan hasil wawancara dan observasi untuk mengetahui penerapan reward and punishment satker terhadap kinerja pegawai yang dihasilkan paska diklat berjalan dengan baik atau positif karena diterapkannya reward and punishment di satkernya masing-masing. Yang menjadi indikator hasil dokumentasi perilaku kerja dan kinerja peserta paska diklat administrasi kepegawaian, yaitu: 5 indikator yang harus dimiliki oleh peserta diantaranya profil pegawai, SKP/Sasaran Kinerja Pegawai, Prestasi pegawai, Kedisiplinan, dan capaian kinerja. Dari 5 indikator tersebut hanya 4 indikator yang peserta penuhi, diantaranya profil pegawai, SKP/Sasaran Kinerja Pegawai, Prestasi pegawai, dan kedisiplinan. Namun ada I indikator dari peserta yang tidak bisa dipenuhi, yaitu: tentang capaian kinerja.

Pelaksanaan program DAK pada Kantor Wilayah Kementerian Agama Provinsi DKI Jakarta Tahun 2016 dikategorikan Tidak Berhasil (Belum Sepenuhnya Memenuhi Kriteria Keberhasilan), sebab terdapat simpulan analisis yang negatif. Sedangkan pelaksanaan program DAK pada Kantor Kementerian Agama Kota Administrasi Jakarta Pusat dan Kantor Kementerian Agama Kota Administrasi Jakarta Selatan Tahun 2016 dikategorikan Berhasil (Memenuhi Kriteria Keberhasilan), sebab seluruh simpulan analisis positif. Dengan demikian secara keseluruhan dapat pula disimpulkan bahwa pada level evaluasi behavior, pelaksanaan program DAK secara umum pada Balai Diklat Keagamaan Kementerian Agama 
Fahmy Zakiyuddin

Djaali

dikategorikan

Tidak Berhasil

Memenuhi

(Belum

Kriteria

Keberhasilan), sebab secara keseluruhan pada 3 (tiga) satker yang menjadi objek penelitian, belum sepenuhnya memenuhi kriteria keberhasilan. Adapun indikator-indikator evaluasi yang tidak memenuhi kriteria keberhasilan pada satker, sebagaimana dijelaskan pada bab sebelumnya.

Pada level evaluasi result, hasil analisis menunjukkan bahwa pelaksanaan program DAK pada Kantor Wilayah Kementerian Agama Provinsi DKI Jakarta Tahun 2016, Kantor Kementerian Agama Kota Administrasi Jakarta Pusat dan Kantor Kementerian Agama Kota Administrasi Jakarta Selatan dikategorikan Berhasil (Memenuhi Kriteria Keberhasilan), sebab seluruh simpulan analisis positif. Dengan demikian secara keseluruhan dapat pula disimpulkan bahwa pada level evaluasi result, pelaksanaan program DAK secara umum pada Balai Diklat Keagamaan Kementerian Agama dikategorikan Berhasil (Memenuhi Kriteria Keberhasilan), sebab secara keseluruhan pada 3 (tiga) satker yang menjadi objek penelitian, seluruhnya memenuhi kriteria keberhasil

\section{Kesimpulan}

Berdasarkan hasil analisis pada keempat level evaluasi di atas, maka dapat disimpulkan bahwa: I) level reaction sudah memenuhi kriteria keberhasilan, 2) level learning sudah memenuhi kriteria keberhasilan, 3) level behavior belum sepenuhnya memenuhi kriteria keberhasilan, dan 4) level result sudah memenuhi kriteria keberhasilan. Dengan demikian dapat disimpulkan bahwa secara umum pelaksanaan Program DAK
Evaluasi Program Diklat Administrasi Kepegawaian Pada Balai Diklat Keagamaan Kementerian Agama Jakarta (Implementasi Model Evaluasi Kirkpatrick)

pada Balai Diklat Keagamaan Kementerian Agama Jakarta dikategorikan Berhasil (Memenuhi Kriteria Keberhasilan), sebab secara keseluruhan pada 3 (tiga) satker yang menjadi objek penelitian, seluruhnya telah memenuhi kriteria keberhasilan, yakni di mana minimal 3 dari 4 level evaluasi pada masing-masing objek penelitian memenuhi kriteria keberhasilan. Meskipun masih terdapat beberapa aspek/komponen yang perlu diperbaiki dan ditingkatkan demi tercapainya tujuan program.

\section{Daftar Pustaka}

Basri, Hasan dan Rusdiana. (20I5). Manajemen Pendidikan dan Pelatihan. Bandung: CV. Pustaka Setia.

E.B. Johnson. (2006). Contextual Teaching \& Learning. Bandung: MLC.

Harizal Mudjito dan Elfindri. (20I2). Pendidikan Inklusif. Jakarta: Baduose Media Jakarta.

Jack J. Philip. (199I). Handbook of Training Evaluation Measurement Methode. Texas: Gulf Publishing.

Peraturan Pemerintah Nomor I0I Tahun 200I tentang Jenis-jenis Pendidikan dan Pelatihan Pegawai Negeri Sipil, pasal 8 ayat (2).

Redja Mudyahardjo. (2008). Filsafat Ilmu Pendidikan: Suatu Pengantar. Bandung: PT Remaja Rosdakarya. 